\title{
Neuronal histamine and expression of corticotropin-releasing hormone, vasopressin and oxytocin in the hypothalamus: relative importance of $\mathrm{H}_{1}$ and $\mathrm{H}_{2}$ receptors
}

\author{
Andreas Kjær, Philip J Larsen ${ }^{1}$, Ulrich Knigge, Henrik Jørgensen and Jørgen Warberg \\ Departments of Medical Physiology and ${ }^{1}$ Medical Anatomy, The Panum Institute, University of Copenhagen, Copenhagen, Denmark \\ (Correspondence should be addressed to A Kjer, Department of Medical Physiology, Division of Endocrinology and Metabolism, The Panum Institute \\ (Building 12·3), University of Copenhagen, Blegdamsvej 3, DK-2200 Copenhagen N, Denmark)
}

\begin{abstract}
Centrally administered histamine (HA) stimulates the secretion of the pro-opiomelanocortin-derived peptides ACTH and $\beta$-endorphin as well as prolactin. The effect of HA on secretion of these adenohypophysial hormones is indirect and may involve activation of hypothalamic neurons containing corticotropin-releasing hormone (CRH), arginine-vasopressin (AVP) or oxytocin (OT).

We studied the effect of activating central HA receptors by central infusion of HA, HA agonists or antagonists on expression of CRH, AVP and OT mRNA in the hypothalamic paraventricular (PVN) and supraoptic (SON) nuclei.

Intracerebroventricular infusion of $\mathrm{HA}(270 \mathrm{nmol})$, the $\mathrm{H}_{1}$-receptor agonist 2-thiazolylethylamine or the $\mathrm{H}_{2}$-receptor agonist 4-methylhistamine increased the level of CRH mRNA in the PVN, and OT mRNA in the SON. In contrast, none of these compounds had any effect on expression of AVP mRNA in the PVN or SON. Administration of the $\mathrm{H}_{1}$-receptor antagonist mepyramine or the $\mathrm{H}_{2}$-receptor antagonist cimetidine had no effect on basal expression of CRH, AVP or OT mRNA in the PVN and/or SON except for a slight inhibitory effect of cimetidine on CRH mRNA expression in the PVN. Pretreatment with mepyramine or cimetidine before HA administration inhibited the HA-induced increase in OT mRNA levels but had no effect on the HA-induced increase in CRH mRNA levels in the PVN.

We conclude that HA stimulates hypothalamic CRH and OT neurons by increasing mRNA levels, and this effect seems to be mediated via activation of both $\mathrm{HA} \mathrm{H}_{1}$ and $\mathrm{H}_{2}$ receptors.
\end{abstract}

European Journal of Endocrinology 139 238-243

\section{Introduction}

Histamine (HA), which acts as a hypothalamic neurotransmitter (1), participates in the central regulation of anterior pituitary hormone secretion and stimulates secretion of the pro-opiomelanocortin-derived peptides adrenocorticotropin (ACTH) and $\beta$-endorphin as well as prolactin (2). Furthermore, histaminergic neurons, which originate exclusively in the posterior hypothalamus (1), seem to be involved in the mediation of stressinduced release of these hormones (2). Since HA does not appear to stimulate ACTH/ $\beta$-endorphin $(3,4)$ or prolactin secretion $(5,6)$ directly at the pituitary level, its action may be indirect via activation of hypothalamic neurons, which subsequently release hypophysiotropic factors which stimulate pituitary hormone secretion. Corticotropin-releasing hormone $(\mathrm{CRH})$ as well as arginine-vasopressin (AVP) and oxytocin (OT) are involved in regulation of ACTH and $\beta$-endorphin ( 7 . 8) secretion, and AVP and OT are also involved in control of prolactin secretion (9). Therefore activation of CRH-, AVP- and OT-containing neurons may be essential for the HA-induced release of pituitary hormones. In accordance with this hypothesis, hypothalamic nuclei, including the paraventricular nucleus (PVN) and the supraoptic nucleus (SON), which contain CRH, AVP and OT neurons (10), are innervated by histaminergic fibers $(11,12)$, which thereby provide the anatomical basis for a functional interrelation between histaminergic neurons and $\mathrm{CRH}$, AVP and OT neurons. Furthermore, we have recently found that centrally administered HA stimulates the expression of c-fos in hypothalamic CRH, AVP and OT neurons (13) and the formation of CRH, AVP and OT mRNA in the hypothalamus (14), suggesting that these neurons are activated by HA. Finally, we have shown that centrally administered HA releases AVP and OT into peripheral plasma (15) and CRH into pituitary portal blood (16). These findings also support our previous finding that HA is an important regulator of AVP and OT as peripheral hormones since histaminergic blockade inhibits dehydration-induced AVP secretion (17) and suckling-induced OT secretion (18).

The aim of the present study was to characterize histaminergic activation of hypothalamic CRH, AVP 
and OT neurons further, with special emphasis on the type of postsynaptic HA receptor involved. To do so, we studied the effect of centrally administered HA, HA agonists and HA antagonists on the levels of mRNA for $\mathrm{CRH}, \mathrm{AVP}$ and OT in the PVN and SON in conscious male rats.

\section{Materials and methods}

\section{Animals}

Male rats of the Wistar strain (275-325 g) bred at the Panum Institute were housed under controlled conditions of temperature $\left(22^{\circ} \mathrm{C}\right)$, relative humidity $(45-$ $50 \%$ ) and lighting (lights on between 0600-1800 h daily). The rats had free access to laboratory chow and tap water.

\section{Compounds}

The compounds used were HA dihydrochloride (molecular weight of HA, 111; Sigma Chemicals, St Louis, MO, USA), the $\mathrm{H}_{1}$-receptor agonist 2-thiazolylethylamine (2-TEA; molecular weight 128; gift from Smith, Kline \& Beecham, Welwyn Garden City, Herts, UK) (19), the $\mathrm{H}_{2}$-receptor agonist 4-methylhistamine (4-MeHA; molecular weight 126; gift from Smith, Kline \& Beecham) (19), the $\mathrm{H}_{1}$-receptor antagonist mepyramine (MEP; molecular weight 286; gift from DAK Laboratories, Copenhagen, Denmark) (19), and the $\mathrm{H}_{2}$ receptor antagonist cimetidine (CIM; molecular weight 252; gift from Smith, Kline \& Beecham) (19).

\section{Surgical and experimental procedures}

At 5-7 days before experimentation, a permanent metal cannula was implanted into the right lateral ventricle of the brain of all rats for i.c.v. infusions. The cannula was positioned as previously described (coordinates $1.5 \mathrm{~mm}$ lateral from the bregma on the coronal suture, $4.5 \mathrm{~mm}$ below the surface of the skull) (20). Implantation was performed during pentobarbital anesthesia (60 mg/kg i.p.).

All experiments were performed in conscious freely moving rats and between 1000 and $1200 \mathrm{~h}$. On the day of experimentation the i.c.v. cannulas were extended by silastic tubing and the rats were left undisturbed in individual cages in a quiet room for an adaptation period of at least $90 \mathrm{~min}$.

\section{Experiment 1: effect of HA or selective $\mathrm{H}_{1}$ - or $\mathrm{H}_{2}$-receptor activation on CRH, AVP and OT mRNA in the hypothalamic PVN and SON}

HA $(270 \mathrm{nmol})$, the $\mathrm{H}_{1}$-receptor agonist 2-TEA (2180 nmol), the $\mathrm{H}_{2}$-receptor agonist 4-MeHA $(790 \mathrm{nmol})$ or saline (control) was infused i.c.v. $(5 \mu \mathrm{l} ; 2 \mu \mathrm{l} / \mathrm{min})$ at
-240 min. The dose of HA was chosen to stimulate significantly but submaximally the secretion of ACTH, $\beta$-endorphin (21) and prolactin (22). This dose was previously shown to be able to stimulate neuropeptide mRNA levels (14). The doses of 2-TEA and 4-MeHA were chosen to be equipotent to the HA dose with respect to ACTH release (23).

At time $0 \mathrm{~min}$, the rats were decapitated, and brains were rapidly removed, frozen on dry ice and stored at $-80^{\circ} \mathrm{C}$. The $240 \mathrm{~min}$ period between stimulation and decapitation was chosen as it has previously been shown to be optimal for demonstrating stress-induced changes in CRH mRNA (24). Sections $(12 \mu \mathrm{m})$ were prepared as previously described (13). Synthetic DNA oligonucleotide probes directed against rat $\mathrm{CRH}$ bases 496-543 (25), AVP bases coding for the N-terminal 16 amino acids of the glycopeptide sequence (26), and OT bases 247-294 (26) were used for in situ hybridization. The probes were labeled and hybridization and exposure performed as previously described (13). The exposure times were 3 weeks, 1 day and 2 days for CRH, AVP and OT mRNA respectively. X-ray autoradiograms were quantified using a computer-assisted image analysis system (Image 1.49; Wayne Rasband, NIH, Bethesda, MD, USA), and no attempts to differentiate between subdivisions of the PVN and SON were made. Direct comparison of the effect of histaminergic compounds on neuropeptide mRNA levels between different brain areas was made easier by arbitrarily setting hybridization levels in control animals as 100. Background values from neighboring areas considered to be free of positive hybridization were subtracted from individual sections, thus serving as their own background control.

\section{Experiment 2: effect of selective $\mathrm{H}_{1-}$ or $\mathrm{H}_{2}$ - receptor blockade on basal and $\mathrm{HA}$-induced CRH, AVP and OT mRNA in the hypothalamic PVN and SON}

Rats were pretreated with i.c.v. infusion ( $5 \mu \mathrm{l} ; 2 \mu \mathrm{l} / \mathrm{min})$ of the $\mathrm{H}_{1}$-receptor antagonist MEP (350 nmol), the $\mathrm{H}_{2}$ receptor antagonist CIM $(400 \mathrm{nmol})$ or saline (control) at $-245 \mathrm{~min}$. After $5 \mathrm{~min}$, HA $(270 \mathrm{nmol})$ or saline (control) was infused i.c.v. $(5 \mu \mathrm{l} ; 2 \mu \mathrm{l} / \mathrm{min})$ at time $-240 \mathrm{~min}$.

At time $0 \mathrm{~min}$, the rats were decapitated and their brains rapidly removed and treated as described for experiment 1 .

\section{Statistical analysis}

Data are presented as the mean \pm S.E.M. for five to eight rats. Comparison of the mRNA levels between treatment groups was performed by a one-way ANOVA followed by Duncan's procedure for multiple comparisons where appropriate. $P<0.05$ was considered significant. 


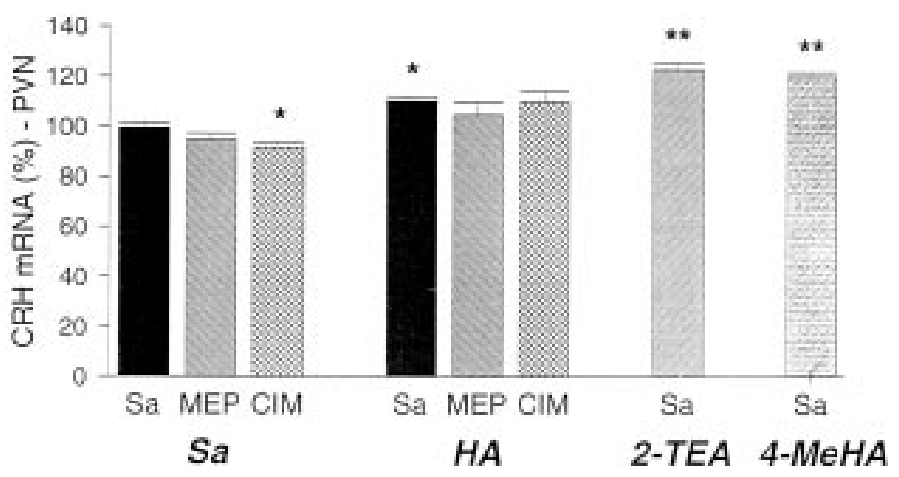

Figure $1 \mathrm{Effect}$ of $\mathrm{HA}, \mathrm{HA}$ agonists or HA antagonists on $\mathrm{CRH}$ mRNA in the PVN. Rats were pretreated at time -245 min with an i.c.v. infusion of the $\mathrm{H}_{1}$-receptor antagonist MEP, the $\mathrm{H}_{2}$-receptor antagonist $\mathrm{CIM}$ or saline (Sa; control). After $5 \mathrm{~min}, \mathrm{HA}$, the $\mathrm{H}_{1}$-receptor agonist 2-TEA, the $\mathrm{H}_{2}$-receptor agonist 4-MeHA or saline (control) was administered. At time $0 \mathrm{~min}$, rats were decapitated and in situ hybridization histochemical analysis of CRH mRNA was performed. The data represent means \pm S.E.M. for five to eight animals. ${ }^{*} P<0.05 ;{ }^{* \star} P<0.01$ vs $\mathrm{Sa}+\mathrm{Sa}$.

\section{Results}

\section{Experiment 1: effect of $\mathrm{HA}$ or selective $\mathrm{H}_{1}$ - or $\mathrm{H}_{2}$-receptor activation on CRH, AVP and OT mRNA in the hypothalamic PVN and SON}

Central administration of $\mathrm{HA}$, the $\mathrm{H}_{1}$-receptor agonist 2-TEA or the $\mathrm{H}_{2}$-receptor agonist 4-MeHA increased CRH mRNA levels in the PVN by $10 \%$ to $25 \%$ (Fig. 1; $P<0.05 / P<0.01$ ).

The levels of AVP mRNA in both the PVN and SON were unaffected by infusion of HA, 2-TEA or 4-MeHA (Figs 2 and 3).

The OT mRNA level in the SON increased by more than $50 \%$ after infusion of HA, 2-TEA or 4-MeHA (Fig. 4; $P<0.01$ ).

\section{Experiment 2: effect of selective $\mathrm{H}_{1}-$ or $\mathrm{H}_{2}$ - receptor blockade on basal and $\mathrm{HA}$-induced CRH, AVP and OT mRNA in the hypothalamic PVN and SON}

Except for a slight inhibitory effect of the $\mathrm{H}_{2}$-receptor antagonist CIM on basal CRH mRNA levels (Fig. 1;
$P<0.05)$, treatment with the $\mathrm{H}_{1}$-receptor antagonist MEP or CIM had no effect on basal expression of CRH, AVP and OT mRNA in the PVN and/or SON.

HA-induced CRH expression was not significantly affected by MEP or CIM (Fig. 1). When MEP was administered before HA, which on its own had no stimulatory effect upon AVP mRNA expression, a lower level of AVP mRNA was observed in the PVN and SON (Figs 2 and 3; $P<0.05$ ). Pretreatment with CIM did not have this effect (Figs 2 and 3). Both MEP and CIM inhibited the HA-induced rise in OT mRNA levels (Fig. 4; $P<0.01$ ).

\section{Discussion}

We found that centrally administered HA increased the level of CRH mRNA in the PVN, indicating that HA may have a role as a central stimulatory neurotransmitter activating $\mathrm{CRH}$ neurons. In accordance with this, we have previously found that HA induces expression of c-fos, an indicator of early neuronal activation $(27,28)$, in CRH-immunoreactive neurons of the PVN (13). The effect seems to be caused by $\mathrm{H}_{1}$ - and $\mathrm{H}_{2}$-receptor activation since administration of an $\mathrm{H}_{1}$ - as well as an

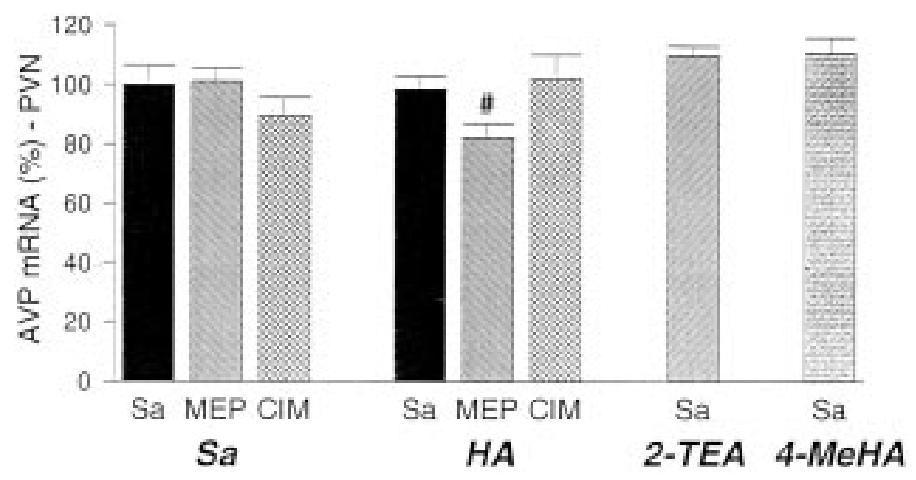

Figure 2 Effect of HA, HA agonists or HA antagonists on AVP mRNA in the PVN. At time 0 min, rats were decapitated and in situ hybridization histochemical analysis of AVP mRNA performed. For further details, see the legend to Fig. 1 . \#P $<0.05$ vs Sa $+\mathrm{HA}$. 


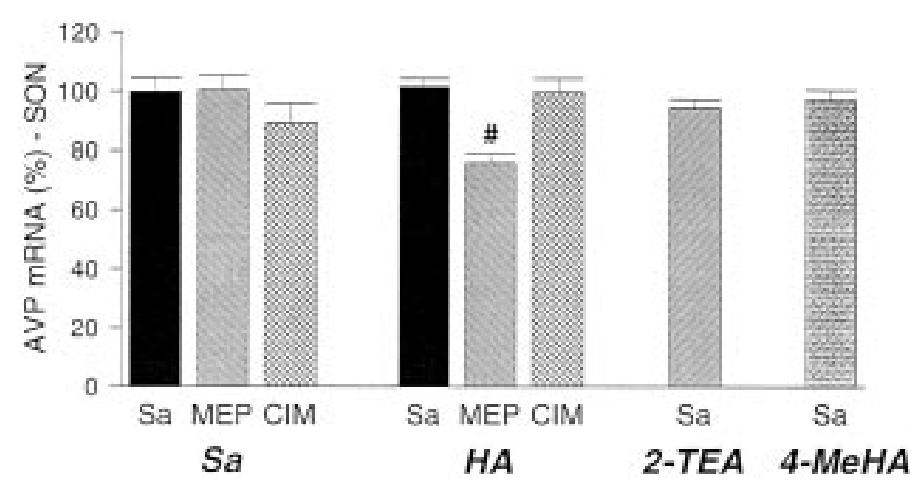

Figure 3 Effect of HA, HA agonists or HA antagonists on AVP mRNA in the SON. At time 0 min, rats were decapitated and in situ hybridization histochemical analysis of AVP mRNA performed. For further details, see the legend to Fig. $1 \# P<0.05$ vs Sa $+\mathrm{HA}$.

$\mathrm{H}_{2}$-receptor agonist stimulated the expression of $\mathrm{CRH}$ mRNA. The CRH neurons in the PVN mainly project to the external layer of the median eminence where they release $\mathrm{CRH}$ into the pituitary portal blood. The present data are therefore in accordance with our previous findings that $\mathrm{H}_{1}$ - and $\mathrm{H}_{2}$-receptor activation by the same agonists, as used here and in similar doses, stimulated $\mathrm{CRH}$ release into the long pituitary portal vessels in anesthetized rats (16). It is therefore likely that the previously demonstrated stimulatory effect of $\mathrm{H}_{1}$ - and $\mathrm{H}_{2}$-receptor agonists on ACTH and $\beta$-endorphin secretion $(16,23)$ is mediated at least in part by activation of $\mathrm{CRH}$ neurons. In support of this hypothesis, the agonist-induced ACTH and $\beta$-endorphin secretion was inhibited by immunoneutralization of endogenous $\mathrm{CRH}$ (16). $\mathrm{H}_{2}$-receptor blockade by CIM inhibited slightly basal expression of $\mathrm{CRH}$ mRNA whereas $\mathrm{H}_{1}$-receptor blockade had no such effect. This may indicate the existence of a basal $\mathrm{H}_{2}$-receptor-mediated histaminergic tone on CRH synthesis. However, this effect is not important for basal ACTH and $\beta$-endorphin secretion since CIM did not influence basal secretion of these hormones (23). Neither the $\mathrm{H}_{1}$ - nor the $\mathrm{H}_{2}$-receptor antagonist inhibited the HA-induced increase in $\mathrm{CRH}$
mRNA. We have no obvious explanation for this somewhat surprising observation, but the changes in $\mathrm{CRH}$ mRNA levels were small and the risk of type II error significant, i.e. there may have been differences that we could not detect. However, another explanation could be that blockade of both receptors is necessary to obtain inhibition of the HA-induced increase in $\mathrm{CRH}$ mRNA. Also in contrast to the present results is the inhibitory effect of MEP and CIM on HA-induced ACTH and $\beta$-endorphin secretion (23). However, this could be due to the fact that release may take place without changes in $\mathrm{CRH}$ synthesis as these are not necessarily coupled (A G Watts, personal communication), and that the synergistic effects between CRH and AVP/OT allows for small simultaneous changes in $\mathrm{CRH}$ and AVP/OT to cause greater changes in ACTH and $\beta$-endorphin levels.

The present finding that $\mathrm{HA}$ or selective $\mathrm{H}_{1}$ - and $\mathrm{H}_{2}$ receptor agonists did not affect AVP mRNA levels in the PVN or SON is in contrast with our previous observations that AVP mRNA increased a little in the PVN in response to HA (14). However, the difference found in the previous study (14) was small and we may very well have overlooked a minor effect in the present

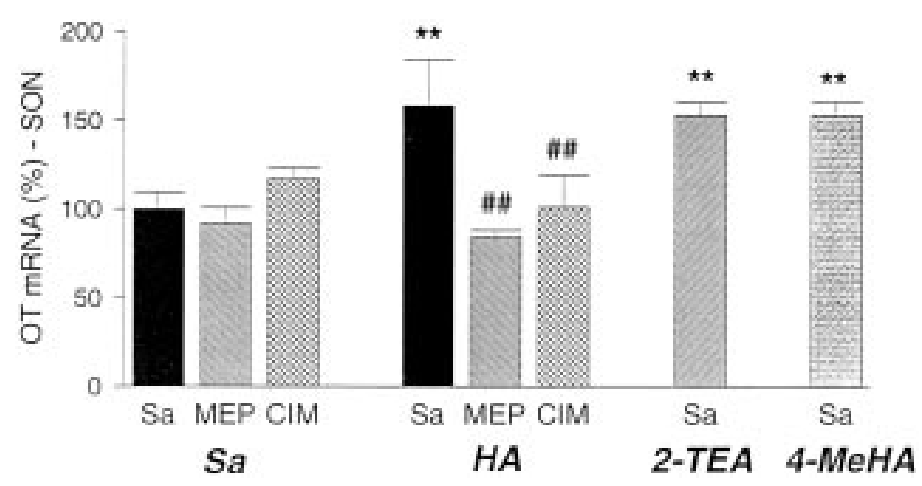

Figure 4 Effect of HA, HA agonists or HA antagonists on expression of OT mRNA in the SON. At time 0 min, rats were decapitated and in situ hybridization histochemical analysis of OT mRNA performed. For further details, see the legend to Fig. $1 .{ }^{* *} P<0.01 \mathrm{vs} \mathrm{Sa}+\mathrm{Sa}$; $\# \# P<0.01$ vs Sa + HA. 
experiment (statistical type II error). Indeed, there is a slight tendency of an $\mathrm{H}_{1}$ - and $\mathrm{H}_{2}$-receptor-mediated stimulation in the PVN but not in the SON. However, we cannot rule out the possibility that the previously found effect was an accidental finding. Furthermore, since we cannot discriminate between parvo- and magno-cellular neurons and since the signal from parvocellular neurons is overshadowed by that from magnocellular ones, a significant increase in AVP mRNA in parvocellular neurons may very well have taken place.

The basal expression of AVP mRNA was unaffected by $\mathrm{H}_{1}$ - or $\mathrm{H}_{2}$-receptor blockade, indicating the lack of basal histaminergic tone on AVP synthesis. In accordance with this, we previously found that basal AVP mRNA expression was unaffected by HA synthesis (29). In contrast, blockade of the histaminergic system may inhibit AVP mRNA levels when the vasopressinergic system is activated. This is supported by our observation that blockade of $\mathrm{HA}$ synthesis during dehydration attenuated the increase in AVP mRNA (29). Both $\mathrm{H}_{1-}$ and $\mathrm{H}_{2}$-receptor activation causes release of AVP (17), but as seen in the present study not to an extent where synthesis is stimulated. This is probably due to the short duration of the histaminergic stimuli and the small fractional amount of stored AVP being released in response to the stimulation. However, using intronic probes might have demonstrated expression of AVP. The fact that centrally administered HA induced expression of c-fos in AVP-immunoreactive neurons of the PVN and SON (13) indicates that AVP neurons can be activated by HA. In support of this are recent observations of the ability of HA to depolarize AVP neurons in the SON probably via an $\mathrm{H}_{1}$-receptor mechanism (30).

The inhibitory effect of combined MEP and HA administration on mRNA levels of AVP in the PVN and SON is difficult to explain. The combination of MEP and HA should be equivalent to $\mathrm{H}_{2}$-receptor activation but the result was different from that observed with 4-MeHA alone.

The stimulatory effect of HA on ACTH/ $\beta$-endorphin and prolactin secretion is in part mediated via AVP (21, 22 ) and exerted via $V_{1}$ and $V_{2}$ receptors $(31,32)$. On this basis, it is surprising that histaminergic activation has no effect on AVP mRNA levels. However, as mentioned for $\mathrm{CRH}$, small changes in AVP may in synergy with changes in $\mathrm{CRH}$ lead to significant effects on ACTH and $\beta$-endorphin secretion. Furthermore, the role of AVP in HA-induced secretion of ACTH, $\beta$ endorphin and prolactin is in part permissive $(33,34)$, and does not involve changes in AVP secretion and thereby in synthesis.

In accordance with our previous experiments (14), we found that HA strongly stimulated expression of OT mRNA in the SON. Together with a previous study where we found that HA induced c-fos expression in OT-immunoreactive neurons of the SON and PVN (13), this indicates that HA activates oxytocinergic neurons.
The effect of HA on OT mRNA seems to be mediated via activation of both $\mathrm{H}_{1}$ and $\mathrm{H}_{2}$ receptors since the effect was blocked by selective blockade of $\mathrm{H}_{1}$ or $\mathrm{H}_{2}$ receptors. In accordance with this, both the $\mathrm{H}_{1}$ - and $\mathrm{H}_{2}$-receptor agonists increased the expression of OT mRNA. We have previously found that OT release into peripheral plasma is stimulated by both $\mathrm{H}_{1}$ - and $\mathrm{H}_{2}$-receptor activation (15), whereas HA has no effect upon release of OT into pituitary portal blood (16), indicating that mainly magnocellular OT neurons of the hypothalamo-neurohypophysial system are activated by HA. Electrophysiological studies have demonstrated that HA has either no effect (30), or an inhibitory one probably via an $\mathrm{H}_{2}$-receptor mechanism, on OT neurons in the $\mathrm{SON}$ (35). A possible explanation for the discrepant results is that the stimulatory effect found is exerted via HA receptors located on interneurons, whereas the electrophysiological studies investigated the direct effect of HA on OT neurons.

In summary, we found that $\mathrm{HA}$ as well as an $\mathrm{H}_{1}$ - or $\mathrm{H}_{2}$-receptor agonist stimulated expression of $\mathrm{CRH}$ and OT mRNA in the PVN and SON respectively. In contrast, $\mathrm{HA}$ or the $\mathrm{H}_{1}$ - or $\mathrm{H}_{2}$-receptor agonist had no effect on AVP mRNA levels in the PVN or SON. Pretreatment with $\mathrm{H}_{1}$ - or $\mathrm{H}_{2}$-receptor antagonists inhibited the HAinduced increase in OT mRNA levels but had no effect on the HA-induced increase in CRH mRNA levels.

\section{Acknowledgements}

This study was supported by grants from The Research Foundation of the Danish Medical Association, Gerda and Aage Haensch' Foundation, The Danish Medical Research Council, Jacob and Olga Madsen's Foundation, Ib Henriksen's Foundation, the NOVO Foundation, Nordic Insulin Foundation, and the Velux Foundation. We thank Elsa Larsen for skilled technical assistance.

\section{References}

1 Schwartz JC, Arrang JM, Garbarg M, Pollard H \& Ruat M. Histaminergic transmission in the mammalian brain. Physiological Reviews 19917 11-51.

2 Knigge U \& Warberg J. The role of histamine in the neuroendocrine regulation of pituitary hormone secretion. Acta Endocrinologica 199112 4609-4619.

3 Hashimoto K, Yunoki S, Takahara J \& Ofuji T. ACTH release in pituitary cell cultures. Effect of neurogenic peptides and neurotransmitter substances on ACTH release induced by hypothalamic corticotropin releasing factor (CRF). Endocrinologia Japonica 197926 103-109.

4 Vermes I, Mulder GH, Smelik PG \& Tilders FJ. Differential control of beta-endorphin/beta-lipotropin secretion from anterior and intermediate lobes of the rat pituitary gland in vitro. Life Sciences $1980271761-1768$.

5 Libertun C \& McCann SM. The possible role of histamine in the control of prolactin and gonadotropin release. Neuroendocrinology $197620110-120$.

6 Knigge U, Matzen S \& Warberg J. Histaminergic stimulation of prolactin secretion mediated via H1- or H2-receptors: dependence on routes of administration. Neuroendocrinology 198644 41-48. 
7 Antoni FA. Hypothalamic control of adrenocorticotropin secretion: advances since the discovery of 41-residue corticotropinreleasing factor. Endocrine Reviews $19867351-378$.

8 Jones MT \& Gillham B. Factors involved in the regulation of adrenocorticotropic hormone/beta-lipotropic hormone. Physiological Reviews $198868743-818$.

9 Ben-Jonathan N, Laudon M \& Garris PA. Novel aspects of posterior pituitary function: regulation of prolactin secretion. Frontiers In Neuroendocrinology 199112 231-277.

10 Swanson LW. The hypothalamus. In Handbook of Chemical Neuroanatomy. Vol. 5: Integrated Systems of the CNS. Part I: Hypothalamus, Hippocampus, Amygdala, Retina, pp 1-37. Eds A Björklund, T Hökfelt, LW Swanson. Amsterdam: Elsevier, 1987.

11 Inagaki N, Yamatodani A, Ando-Yamamoto M, Tohyama M, Watanabe T \& Wada H. Organization of histaminergic fibers in the rat brain. Journal of Comparative Neurology 1988273 283-300.

12 Panula P, Pirvola U, Auvinen S \& Airaksinen MS. Histamineimmunoreactive nerve fibers in the rat brain. Neuroscience 1989 28 585-610.

13 Kjær A, Larsen PJ, Knigge U, Møller M \& Warberg J. Histamine stimulates c-fos expression in hypothalamic vasopressin-, oxytocin-, and corticotropin-releasing hormone-containing neurons. Endocrinology $1994134482-491$.

14 Kjær A, Larsen PJ, Knigge U \& Warberg J. Histaminergic activation of the hypothalamic-pituitary-adrenal axis. Endocrinology $19941351171-1177$.

15 Kjær A, Knigge U \& Warberg J. Involvement of oxytocin in histamine- and stress-induced ACTH and prolactin secretion. Neuroendocrinology 199561 704-713.

16 Kjær A, Knigge U, Plotsky PM, Bach FW \& Warberg J. Histamine H1- and H2-receptor activation stimulates ACTH and betaendorphin secretion by increasing corticotropin-releasing hormone in hypophysial portal blood. Neuroendocrinology 199256 $851-855$.

17 Kjær A, Knigge U, Rouleau A, Garbarg M \& Warberg J. Dehydration-induced release of vasopressin involves activation of hypothalamic histaminergic neurons. Endocrinology 1994135 675-681.

18 Schagen FHE, Knigge U, Kjær A, Larsen PJ \& Warberg J. Involvement of histamine in suckling-induced release of oxytocin prolactin and adrenocorticotropin in lactating rats. Neuroendocrinology 199663 550-558.

19 Ganellin CR. Chemistry and structure-activity relationship of drugs acting on histamine receptors. In Pharmacology of Histamine Receptors, pp 10-102. Eds CR Ganellin, ME Parsons. Bristol: Wright, 1982.

20 Knigge U, Matzen S \& Warberg J. Histaminergic mediation of the stress-induced release of prolactin in male rats. Neuroendocrinology $19884768-74$

21 Kjær A, Knigge U, Bach FW \& Warberg J. Histamine- and stressinduced secretion of ACTH and beta-endorphin: involvement of corticotropin-releasing hormone and vasopressin. Neuroendocrinology $199256419-428$.
22 Kjær A, Knigge U, Olsen L, Vilhardt H \& Warberg J. Mediation of the stress-induced prolactin release by hypothalamic histaminergic neurons and the possible involvement of vasopressin in this response. Endocrinology 1991128 103-110.

23 Knigge U, Bach FW, Matzen S, Bang P \& Warberg J. Effect of histamine on the secretion of pro-opiomelanocortin derived peptides in rats. Acta Endocrinologica $1988119312-319$.

24 Harbuz MS \& Lightman SL. Responses of hypothalamic and pituitary mRNA to physical and psychological stress in the rat. Journal of Endocrinology 1989122 705-711.

25 Jingami H, Mizuno N, Takahashi H, Shibahara S, Furutani Y, Imura H \& Numa S. Cloning and sequence analysis of cDNA for rat corticotropin-releasing factor precursor. FEBS Letters 1985 $19163-66$.

26 Ivell R \& Richter D. Structure and comparison of the oxytocin and vasopressin genes from rat. Proceedings of the National Academy of Sciences of the USA $1984812006-2010$.

27 Sheng M \& Greenberg ME. The regulation and function of c-fos and other immediate early genes in the nervous system. Neuron 19904 477-485.

28 Morgan JI \& Curran T. Stimulus-transcription coupling in the nervous system: involvement of the inducible proto-oncogenes fos and jun. Annual Review of Neuroscience 199114 421-451.

29 Kjær A, Larsen PJ, Knigge U \& Warberg J. Dehydration stimulates hypothalamic gene expression of histamine synthesis enzyme: importance for neuroendocrine regulation of vasopressin and oxytocin secretion. Endocrinology 1995136 2189-2197.

30 Smith BN \& Armstrong WE. The ionic dependence of the histamine-induced depolarization of vasopressin neurones in the rat supraoptic nucleus. Journal of Physiology 1996495 465-478.

31 Kjær A, Knigge U \& Warberg J. Histamine- and stress-induced prolactin secretion: importance of vasopressin V1- and V2receptors. European Journal of Endocrinology 1994131 1-7.

32 Kjær A, Knigge U, Vilhardt H, Bach FW \& Warberg J. Involvement of vasopressin V1- and V2-receptors in histamine- and stressinduced secretion of ACTH and beta-endorphin. Neuroendocrinology $199357503-509$.

33 Kjær A, Knigge U, Vilhardt $\mathrm{H}$ \& Warberg J. Involvement of vasopressin in histamine- and stress-induced prolactin release: permissive, mediating or potentiating role? Neuroendocrinology 199357 314-321.

34 Kjær A, Knigge U, Bach FW \& Warberg J. Permissive, mediating and potentiating effects of vasopressin in the ACTH and betaendorphin response to histamine and restraint stress. Neuroendocrinology $199358588-596$.

35 Yang OZ \& Hatton GI. Histamine mediates fast synaptic inhibition of rat supraoptic oxytocinergic neurons via chloride conductance activation. Neuroscience $199461955-964$.

Received 18 December 1997

Accepted 7 April 1998 